\title{
PENERBITAN PERATURAN PEMERINTAH PENGGANTI UNDANG- UNDANG NOMOR 1 TAHUN 2020 SEBAGAI STRATEGI KEBIJAKAN PAJAK PEMERINTAH INDONESIA DALAM MENGHADAPI DAMPAK PANDEMI COVID-19 TERHADAP KEUANGAN NEGARA
}

\author{
Anton Aulawi \\ Universitas Banten Jaya \\ Serang, Indonesia \\ antonaulawi@unbaja.ac.id
}

\begin{abstract}
The impact of the Covid-19 pandemic has greatly affected global and national economic order. The existence of physical distancing policies, as well as large-scale social restrictions, greatly affected the activities of tourism and manufacturing sectors, causing the economic growth to slow down. Therefore, the government issued a tax policy by stimulating Government Regulation in Lieu of Law Number 1 of 2020 concerning State Financial Policy and Financial System Stability for Handling the Corona Virus Disease (Covid-19) Pandemic on March 31, 2020 and Regulation of the Minister of Finance which regulates tax incentives known as tax relaxation. This research was conducted using qualitative method A qualitative method was used to produce in-depth descriptions of speech, writing and observable behavior of an individual, community group and organization in a certain context that was studied from a comprehensive and holistic point of view. The results of this study were that the Indonesian Government has established various tax policy strategies during the Covid-19 pandemic which aim to achieve the target of state revenue, by revising tax revenue targets, rearranging state revenue allocations in the 2020 State Revenue and Expenditure Budget and implementing taxes. Trading Through Electronic Systems. The government has also relaxed the imposition of Article 21 Income Tax, Article 22 Income Tax, Article 25 Income Tax, and specific VAT tax returns to the manufacturing sector. So the relaxation of income tax in articles 21, 22 and 25 as well as tax returns was the most effective and appropriate way to overcome the impact of Indonesia's economy in the face of the Covid-19 outbreak.
\end{abstract}

Keywords: Policy, Tax, Covid-19.

\section{PENDAHULUAN}

Dunia internasional dalam beberapa bulan terakhir ini tengah dikejutkan dengan sebuah pandemi, yaitu wabah suatu penyakit yang disebabkan oleh virus bernama corona atau lebih dikenal dengan istilah Corona Virus Diseases-19 (Covid-19). Akibat dari pandemi covid-19 ini, menyebabkan diterapkannya berbagai kebijakan untuk memutus mata rantai penyebaran virus covid-19 di Indonesia. Upaya yang dilakukan oleh pemerintah di Indonesia salah satunya dengan menerapkan himbauan kepada masyarakat agar melakukan physical distancing yaitu 
himbauan untuk menjaga jarak diantara masyarakat, menjauhi aktivitas dalam segala bentuk kerumunan, perkumpulan, dan menghindari adanya pertemuan yang melibatkan banyak orang. Upaya tersebut ditujukan kepada masyarakat agar dapat dilakukan untuk memutus rantai penyebaran pandemi Covid-19 yang terjadi saat ini.

\section{Dampak Covid-19 juga} berpengaruh pada perputaran roda perekonomian di dalam negeri, memberikan dampak yang cukup luas terhadap kegiatan perekonomian yang dilakukan masyarakat maupun para pelaku ekonomi khusunya di sektor pariwisata dan manufaktur. Hal tersebut mengharuskan Pemerintah harus mengeluarkan strategi kebijakan baru di bidang ekonomi/moneter/fiskal. Peranan pemerintah dalam meningkatkan pembangunan ekonomi serta memacu pertumbuhan ekonomi terutama di negara yang sedang berkembang dilakukan melalui kebijakan ekonomi/moneter/fiskal khususnya perpajakan. Masyarakat dipengaruhi secara signifikan oleh ekonomi, mulai dari berkurangnya pendapatan (pedagang dll) dan juga pemotongan gaji dan PHK karyawan baik publik maupun swasta. Karena itu pemerintah mengeluarkan salah satu kebijakan relaksasi perpajakan sebagai akibat Pandemi Virus Corona.

Penerimaan pajak turun akibat kondisi ekonomi melemah, dukungan insentif pajak dan penurunan tarif pajak penghasilan $(\mathrm{PPh})$. Penerimaan Negara Bukan Pajak (PNBP) juga turun dampak jatuhnya harga komoditas, pandemi Covid-19 telah mengancam sistem keuangan yang ditunjukkan dengan penurunan berbagai aktivitas ekonomi domestik. Dari sisi pengeluaran, dampak yang diakibatkan Covid-19 ini sangat besar. Mengatasi permasalahan yang timbul akibat Covid-19 ini diharapkan tidak terlalu menekan defisit APBN. Oleh sebab itu, dibutuhkan strategi yang dapat membantu mengatur perekonomian saat ini. Kebijakan fiskal dari sisi penerimaan dan pengeluaran pemerintah ternyata sangat besar perananannya dalam menanggulangi dampak Covid-19.(Dina Eva Santi Silalahi: 2020)

Melalui kebijakan relaksasi perpajakan, diharapkan oleh Pemerintah dapat mempengaruhi tingkat pendapatan nasional, kesempatan kerja, investasi nasional, dan distribusi penghasilan nasional. Penurunan pendapatan akibat wabah Covid-19 itu terutama akan terjadi di sisi penerimaan perpajakan.

Dalam penanganan pandemi Covid-19 Presiden mengambil kebijakan 
dengan menetapkan Peraturan

Pemerintah Pengganti Undang-Undang (Perppu) Nomor 1 Tahun 2020 tentang Kebijakan Keuangan Negara dan Stabilitas Sistem Keuangan untuk Penanganan Pandemi Corona Virus Disease (Covid-19) dan/atau Dalam Rangka Menghadapi Ancaman yang Membahayakan Perekonomian Nasional dan/atau Stabilitas Sistem Keuangan pada tanggal 31 Maret 2020. Perppu Nomor 1 Tahun 2020 tersebut ditetapkan sebagai instrument yuridis dalam penanganan Covid-19 karena telah terbukti pandemi Covid-19 memberi dampak antara lain terhadap perlambatan pertumbuhan ekonomi nasional, penurunan penerimaan negara, dan peningkatan belanja Negara dan pembiayaan. Untuk itu diperlukan upaya pemerintah untuk melakukan penyelamatan kesehatan dan perekonomian nasional, dengan fokus pada belanja untuk kesehatan,jaring pengaman sosial (social safety net), serta pemulihan perekonomian termasuk untuk dunia usaha dan masyarakat yang terdampak. (Henny Juliani: 2020)

Sejauh mana kewenangan Presiden menetapkan Perppu Nomor 1 Tahun 2020 sebagai suatu kebijakan keuangan Negara dan implikasinya terhadap perbaikan ekonomi dan stabilitas keuangan Negara. Melihat dari kebijakan pemerintah tersebut, penulis akan menganalisis dampak kebijakan terhadap pertahanan ekonomi di Indonesia. Berdasarkan latar belakang yang disebutkan di atas maka dilakukan penelitian tentang seberapa efektif relaksasi pajak penghasilan terhadap pertahanan ekonomi Indonesia selama Pandemi Covid-19.

\section{METODE PENELITIAN}

Penelitian yang dilakukan ini menggunakan metode penelitian dengan metode deskriptif kualitatif. Pendekatan kualitatif dilakukan untuk menghasilkan uraian yang mendalam tentang ucapan, tulisan, dan perilaku yang dapat diamati dari suatu individu kelompok masyarakat, dan organisasi dalam suatu konteks tententu yang dikaji dari sudut pandang yang utuh, komprehensif, dan holistik. Penelitian kualitatif merupakan metode pengumpulan dan analisa datanya bersifat non kuantitatif dengan tujuan untuk mengeksplorasi hubungan sosial dan deskripsi realitas yang dialami respon. (Saraclaers:1993). Sedangkan tipe penelitian deskriptif, yaitu untuk menjelaskan suatu peristiwa yang operasionalisasinya berkisar pada pengumpulan data, pengolahan data dan penafsiran data yang diberi makna secara rasional dengan tetap memegang prinsip- 
prinsip logika sehingga terbentuk kesimpulan yang holistik.

Metode penelitian ini juga mengkaji masalah dari sudut pandang hukum dengan menggunakan pendekatan yuridis normatif, karena masalah yang akan diteliti tersebut berhubungan erat dengan law inbooks, artinya pengungkapan permasalahan yang diteliti berpegang pada ketentuan yang normatif dalam hal ini adalah peraturan perundangundangan di bidang moneter dan fiskal/perpajakan yaitu Peraturan Pemerintah Pengganti Undang-Undang (Perppu) Nomor 1 Tahun 2020 tentang Kebijakan Keuangan Negara dan Stabilitas Sistem Keuangan untuk Penanganan Pandemi Corona Virus Disease (Covid-19) dan/atau Dalam Rangka Menghadapi Ancaman yang Membahayakan Perekonomian Nasional dan/atau Stabilitas Sistem Keuangan. Spesifikasi penelitian yang digunakan dalam penelitian ini adalah deskriptif analitis, yang selanjutnya bahan-bahan tersebut akan dianalisis secara kualitatif.

Data diperoleh melalui studi literatur, dengan membaca dan menelaah serta menganalisa berbagai literatur, baik berupa dokumen, jurnal, Peraturan Pemerintah Pengganti Undang-Undang (Perppu) Nomor 1 Tahun 2020, data publikasi dari kementerian keuangan maupun dari website resmi yang mengeluarkan informasi- informasi yang relevan terhadap penelitian. Sementara analisa data dilakukan dengan melakukan reduksi, klasifikasi, pemaknaan hingga penarikan kesimpulan.

\section{HASIL DAN PEMBAHASAN}

\section{a. Tujuan Kebijakan Fiskal}

Menurut Kamus Besar Bahasa Indonesia (KBBI), fiskal berkaitan dengan urusan pajak atau pendapatan negara. Kata fiskal sendiri berasal dari Bahasa Latin, fiscus yaitu nama seorang pemegang kuasa atas keuangan pertama pada zaman Romawi kuno. Secara harfiah berarti keranjang atau tas. Adapun kata fisc dalam bahasa Inggris berarti pembendaharaan atau pengaturan keluar masuknya uang dalam kerajaan. Fiskal digunakan untuk menjelaskan bentuk pendapatan Negara atau kerajaan yang dikumpulkan dari masyarakat dan oleh pemerintahan Negara atau kerajaan dianggap sebagai pendapatan lalu digunakan sebagai pengeluaran dengan program-program untuk menghasilkan pencapaian terhadap pendapatan nasional, produksi dan perekonomian serta digunakan pula sebagai perangkat keseimbangan dalam perekonomian.(I. Wayan Sudirman: 2014). 
Kebijakan fiskal diartikan tindakan kebijaksanaan yang dilakukan oleh pemerintah, yang berkaitan dengan pendapatan dan pengeluaran uang. Kebijakan fiskal adalah kebijakan ekonomi yang dilakukan oleh pihak pemerintah guna mengelola dan mengarahkan kondisi perekonomian ke arah yang lebih baik atau yang diinginkan dengan cara mengubah atau memperbarui penerimaan dan pengeluaran pemerintah, salah satu hal yang ditonjolkan dari kebijakan fiskal ini adalah pengendalian pengeluaran dan penerimaan pemerintah atau negara. Kebijakan fiskal di Indonesia merujuk pada kebijakan pemerintah yang ditujukan untuk mengarahkan ekonomi suatu negara lewat pengeluaran serta pendapatan pemerintah.

Tujuan utama dikeluarkannya kebijakan fiskal adalah untuk menentukan arah, tujuan, sasaran, dan prioritas pembangunan nasional serta pertumbuhan perekonomian bangsa. Adapun tujuantujuan dikeluarkannya kebijakan fiskal secara rinci adalah sebagai berikut. (I. Wayan Sudirman: 2014).

1) Mencapai kestabilan perekonomian nasional.

2) Memacu pertumbuhan ekonomi.

3) Mendorong laju investasi.

4) Membuka kesempatan kerja yang luas.
5) Mewujudkan keadilan sosial.

6) Sebagai wujud pemerataan dan pendistribusian pendapatan.

7) Mengurangi pengangguran.

8) Menjaga stabilitas harga barang dan jasa agar terhindar dari inflasi.

Penentu kebijakan fiskal terbagi menjadi dua komonen yaitu;

1) Pendapatan negara (pajak) sebagai komponen penyusun kebijakan fiskal. Pendapatan negara sebagai komponen penyusun kebijakan fiskal karena sebagai sumber pembangunan, bersifat memaksa dan tercantum dalam konstitusi.

2) Pengeluaran negara atau APBN yang merupakan kumpulan berbagai pengeluaran negara. instrumen APBN terdiri dari pembangunan infrastruktur, pembangunan fasilitas umum, hingga biaya operasional pemerintah.

Kebijakan fiskal dibagi menjadi 2 (dua) yaitu menurut segi teori dan menurut jumlah penerimaan dan pengeluaran.

1) Berdasarkan Teori

Kebijakan fiskal dari segi teori adalah bagaimana kebijakan itu dilihat secara non-praktis. Adapun macammacam kebijakan fiskal dari segi teori adalah: 
a) Kebijakan Fungsional

Merupakan kebijakan untuk pertimbangan pengeluaran anggaran dan penambahan kesempatan kerja yang dilakukan oleh pemerintah karena akibat tidak langsung dari pendapatan nasional.

b) Kebijakan Disengaja

Merupakan kebijakan fiskal yang dimaksudkan untuk mengatasi masalah-masalah ekonomi yang sedang dihadapi dengan cara memanipulasi anggaran belanja secara sengaja, baik melalui perubahan perpajakan maupun perubahan pengeluaran pemerintah.

Ada tiga bentuk dari macam kebijakan fiskal ini, yaitu:

1. Membuat perubahan pada pengeluaran pemerintah

2. Membuat perubahan pada sistem pemungutan pajak

3. Membuat perubahan secara serentak baik pada pengelolaan pemerintah maupun sistem pemungutan pajak

\section{c) Kebijakan Tak Disengaja}

Kebijakan ini dimaksudkan untuk mengendalikan kecepatan siklus bisnis supaya tidak terlalu fluktuatif. Dalam kondisi depresi, kebijakan ini dimaksudkan untuk menambah aktivitas kegiatan ekonomi yang terjadi. Sedangkan dalam keadaan inflasi, kebijakan ini akan mengurangi aktivitas tersebut. Jenis penstabil otomatis atau kebijakan fiskal tak disengaja yaitu pajak proporsional, pajak progresif, kebijakan harga minimum, asuransi pengangguran.

Kebijakan fiskal Negara Indonesia tercermin dalam Anggaran Pendapat Belanja Negara (APBN). Dalam APBN tersebut, terdapat penetapan pemerintah mengenai alokasi dan distribusi keuangan negara. Mengingat urgennya bidang ini dalam pembangunan perekonomian negara. Kebijakan fiskal juga berpengaruh terhadap inflasi. Berdasarkan hasil penelitian Surjaningsih, N.dkk pada tahun 2012 tentang kebijakan fiskal, bahwa dampak kebijakan fiskal terhadap output dan inflasi adalah suatu kondisi kenaikan pengeluaran pemerintah berdampak positif terhadap Produk Domestik Bruto (PDB) sementara kondisi kenaikan pajak berdampak menurunkan PDB. Dampak positif dari pengeluaran pemerintah dan dampak negatif dari pajak terhadap PDB tersebut sejalan dengan teori Keynes tentang peran pemerintah dalam menggerakkan perekonomian serta sesuai dengan penelitian empiris di beberapa negara maju. Pengaruh pengeluaran pemerintah lebih dominan 
terhadap PDB dibandingkan dengan pajak menunjukkan masih cukup efektifnya kebijakan ini untuk menstimulasi pertumbuhan ekonomi khususnya dalam masa resesi dibandingkan dengan pajak. Pengaruh pengeluaran pemerintah terhadap penurunan inflasi kemungkinan dapat dijelaskan oleh dampak multiplier dari pengeluaran pemerintah untuk investasi (diantaranya infrastruktur) yang lebih besar dibandingkan pengeluaran rutin. Pengeluaran pemerintah untuk infrastruktur diperkirakan dapat memperbaiki distribusi barang dan jasa sehingga berkontribusi terhadap penurunan inflasi. Dalam pendekatan Keynes, kebijakan fiskal dapat menggerakkan perekonomian karena peningkatan pengeluaran pemerintah atau pemotongan pajak mempunyai efek multiplier dengan cara menstimulasi tambahan permintaan untuk barang konsumsi rumah tangga. Demikian pula halnya apabila pemerintah melakukan pemotongan pajak sebagai stimulus perekonomian. Pemotongan pajak akan meningkatkan disposable income dan pada akhirnya mempengaruhi permintaan. Kecenderungan rumah tangga untuk meningkatkan konsumsi dengan meningkatkan marginal prospensity to consume (mpc), menjadi rantai perekonomian untuk peningkatan pengeluaran yang lebih banyak dan pada akhirnya terhadap output. (Dina Eva Santi Silalahi: 2020)

Kebijakan fiskal terdiri atas dua instrumen utama, (1) kebijakan pajak dan (2) pengeluaran pemerintah, tapi, kebijakan apapun itu dapat secara langsung mempengaruhi komponenkomponen permintaan secara menyeluruh jatuh pada kebijakan ini. Menurut Sudiyono (1985) variable instrumen kebijakan fiskal dapat berbentuk pajak, transfer pemerintah, subsidi, dan pengeluaran pemerintah. Kebijakan fiskal atau penganggaran memiliki tiga fungsi:(1) fungsi alokasi, (2) fungsi distribusi, dan (3) fungsi stabilisasi. Fungsi alokasi berhubungan dengan persediaan barang-barang sosial dan proses pemanfaatan sumber daya secara menyeluruh untuk produksi barang-barang swasta, barang-barang sosial, dan kombinasi dari barang-barang sosial yang telah dipilih. Fungsi distribusi berhubungan dengan persamaan kesejahteraan dan distribusi pendapatan dalam masyarakat. Selama fungsi stabilisasi ditujukan untuk menstabilkan atau mempertahankan rendahnya tingkat pengangguran, harga atau tingkat inflasi, dan pertumbuhan ekonomi yang telah ditargetkan. (Indra Maipita, Dkk: 2010). 


\section{b. Kebijakan Perpajakan dalam}

Peraturan Pemerintah Pengganti Undang-Undang Nomor 1 Tahun

2020 tentang Kebijakan Keuangan

Negara dan Stabilitas Sistem

Keuangan untuk Penanganan

Pandemi Corona Virus Desease 2019

Pemerintah melalui Direktorat Jenderal Pajak (DJP) Kementerian Keuangan telah menerbitkan sejumlah aturan yang dimaksudkan untuk menjadi insentif bagi wajib pajak yang terkena dampak pandemi Covid-19. Namun demikian, DJP tetap mengimbau wajib pajak untuk tidak menunda kewajiban membayar dan melaporkan pajak untuk mendukung upaya penanganan dan pencegahan pandemi Covid-19. Sejumlah aturan yang telah diterbitkan, yang terbaru adalah Perpu No.1 Tahun 2020. Sebelumnya DJP telah menerbitkan PMK No.23/PMK.03/2020 tentang Insentif Pajak untuk Wajib Pajak Terdampak Virus Corona, dan KEP-156/PJ/2020 tentang Kebijakan Perpajakan Sehubungan Dengan Penyebaran Wabah Virus Corona 2019. (Ikatan Akuntan Indonesia: 2020).

Pertimbangan Terbitnya Perpu Nomor 1 Tahun 2020 Sebagai Strategi Kebijakan Fiskal
1. Dikarena implikasi pandemi Corona Virus Disease 2019 (Covid-19) telah berdampak antara lain terhadap perlambatan pertumbuhan ekonomi nasional, penurunan penerimaan negara, dan peningkatan belanja negara dan pembiayaan, sehingga diperlukan berbagai upaya Pemerintah untuk melakukan penyelamatan kesehatan dan perekonomian nasional, dengan fokus pada belanja untuk kesehatan, jaring pengaman sosial (social safety net) serta pemulihan perekonomian termasuk untuk dunia usaha dan masyarakat yang terdampak;

2. Dikarenakan implikasi pandemi Corona Virus Disease 2019 (COVID19) telah berdampak pula terhadap memburuknya sistem keuangan yang ditunjukkan dengan penurunan berbagai aktivitas ekonomi domestik sehingga perlu dimitigasi bersama oleh Pemerintah dan Komite Stabilitas Sistem Keuangan (KSSK) untuk melakukan tindakan antisipasi (forward looking) dalam rangka menjaga stabilitas sektor keuangan;

Berdasarkan pertimbangan diatas tersebut Pemerintah dan lembaga terkait perlu segera mengambil kebijakan dan langkah-langkah luar biasa dalam rangka penyelamatan perekonomian nasional dan 
stabilitas sistem keuangan melalui berbagai kebijakan relaksasi yang berkaitan dengan pelaksanaan Anggaran Pendapatan dan Belanja Negara (APBN) khususnya dengan melakukan peningkatan belanja untuk kesehatan, pengeluaran untuk jaring pengaman sosial (social safety net), dan pemulihan perekonomian, serta memperkuat kewenangan berbagai lembaga dalam sektor keuangan.

Dalam rangka penanganan pandemi Covid- 19 dan/atau menghadapi ancaman yang membahayakan perekonomian nasional dan/atau stabilitas sistem keuangan, perlu menetapkan kebijakan keuangan negara dan kebijakan stabilitas sistem keuangan. Kebijakan keuangan negara tersebut meliputi kebijakan pendapatan Negara termasuk kebijakan di bidang perpajakan, kebijakan belanja negara termasuk, kebijakan di bidang keuangan daerah, dan kebijakan pembiayaan. Kebijakan stabilitas sistem keuangan sebagaimana dimaksud meliputi kebijakan untuk penanganan permasalahan lembaga keuangan yang membahayakan perekonomian nasional dan/atau stabilitas sistem keuangan.

Kebijakan di bidang perpajakan sebagaimana diatur dalam Perpu No.1 Tahun 2020 ini, meliputi: (Peraturan
Pemerintah Pengganti Undang-Undang Nomor 1 Tahun 2020).

1. Penyesuaian tarif Pajak Penghasilan Wajib Pajak Badan Dalam Negeri Dan Bentuk Usaha Tetap; Penyesuaian tarif Pajak Penghasilan $(\mathrm{PPh})$ Wajib Pajak Badan Dalam Negeri dan Bentuk Usaha Tetap adalah berupa penurunan tarif Pasal 17 ayat (1) huruf $b$ Undang-Undang No.36 Tahun 2008 tentang Pajak Penghasilan dimana tarif pajak $\mathrm{PPh}$ tersebut adalah semula $28 \%$ menjadi:

a. sebesar $22 \%$ (dua puluh dua persen) yang berlaku pada Tahun Pajak 2020 dan Tahun Pajak 2021; dan

b. sebesar $20 \%$ (dua puluh persen) yang mulai berlaku pada Tahun Pajak 2022.

2. Perlakuan perpajakan dalam kegiatan Perdagangan Melalui Sistem Elektronik (PMSE). PMSE ini maksudnya merupakan perdagangan yang transaksinya dilakukan melalui serangkaian perangkat dan prosedur elektronik;

Dalam meningkatkan penerimaan negara, pemerintah akan melaksanakan pajak digital atau Perdagangan Melalui Sistem Elektronik (PMSE). Dalam Perppu 
Nomor 1 Tahun 2020 menyebutkan skema PMSE akan menarik pajak digital baik berupa pajak pertambahan nilai (PPN) maupun $\mathrm{PPh}$. Otoritas pajak dan Kemenkeu sedang menyiapkan peraturan menteri keuangan (PMK) sebagai payung hukum basis PPN dalam PMSE. Sementara untuk, PPh dan pajak atas transaksi digital, akan disiapkan Peraturan Pemerintah (PP). Kegiatan ini sangat relevan untuk dilaksanakan sehubungan dengan semakin meningkatkan aktivitas online yang dilakukan oleh para pelaku ekonomi sebagai dampak dari social distancing maupun PSBB. Aktivitas dengan menggunakan aplikasi zoom meningkat selama masa pandemik ini, sehingga dapat dilakukukan pungutan atas pajak aktivitas kegiatan tersebut. Perdagangan online yang saat ini belum dapat diperoleh datanya oleh pemungut pajak dapat dilakukan pengawasan maupun peraturan yang tegas untuk mematuhi kewajiban pedagang tersebut sebagai wajib pajak yang melakukan aktivitasnya melalui media elektronik.

3. Perpanjangan Waktu Pelaksanaan Hak dan Pemenuhan Kewajiban Perpajakan
Kebijakan pajak yang lain dalam rangka memberikan kemudahan dalam pelaksanaan hak dan atau pemenuhan kewajiban perpajakan akibat adanya pandemi Covid-19, adalah diberikan perpanjangan waktu pelaksanaan hak dan pemenuhan kewajiban perpajakan dengan ketentuan sebagai berikut:

a. Pengajuan keberatan Wajib Pajak yang jatuh tempo pengajuan keberatan sebagaimana dimaksud dalam Pasal 25 ayat (3) UndangUndang Nomor 6 Tahun 1983 tentang Ketentuan Umum dan Tata Cara Perpajakan sebagaimana telah beberapa kali diubah terakhir dengan UndangUndang Nomor 16 Tahun 2009, yaitu 3 bulan berakhir, maka dalam periode keadaan kahar akibat pandemi Covid-19, jatuh tempo pengajuan keberatan tersebut diperpanjang menjadi paling lama 6 (enam) bulan;

b. permohonan pengurangan atau penghapusan sanksi administrasi, pengurangan atau pembatalan ketetapan pajak yang tidak benar, pembatalan hasil pemeriksaan, sebagaimana dimaksud dalam Pasal 36 ayat (1) Undang-Undang Nomor 6 Tahun 1983 tentang 
Ketentuan Umum dan Tata Cara Perpajakan sebagaimana telah beberapa kali diubah terakhir dengan Undang-Undang Nomor 16 Tahun 2009, yang jatuh tempo penerbitan surat ketetapan atau surat keputusan berakhir dalam periode keadaan kahar akibat pandemi Covid-19, jatuh tempo penerbitan surat ketetapan atau surat keputusan tersebut diperpanjang paling lama 6 (enam) bulan.

4. Pemberian kewenangan kepada Menteri Keuangan untuk memberikan fasilitas kepabeanan berupa pembebasan atau keringanan bea masuk dalam rangka penanganan kondisi darurat serta pemulihan dan penguatan ekonomi nasional.

Menteri Keuangan dalam rangka penanganan pandemi Covid-19 memiliki kewenangan untuk memberikan fasilitas kepabeanan berupa pembebasan atau keringanan bea masuk.

Kebijakan Keuangan Negara merupakan salah satu hal yang dibahas dalam Peraturan Pemerintah Pengganti Undang-Undang (Perppu) No.1 Tahun 2020. Dalam Perppu tersebut, Pemerintah memberikan relaksasi perpajakan dengan penyesuaian tarif Pajak Penghasilan $(\mathrm{PPh})$
Wajib Pajak (WP) Dalam Negeri (DN) Badan, dan Badan Usaha Tetap (BUT) yaitu 22\% untuk tahun 2020-2021 dan $20 \%$ mulai tahun 2022. Untuk WP DN yang berbentuk Perseroan Terbatas (PT) dengan jumlah saham diperdagangkan minimal $40 \%$, serta memenuhi persyaratan, dapat memperoleh tarif $3 \%$ lebih rendah dengan syarat tertentu, yang akan diatur dalam Peraturan Pemerintah (PP). Untuk pajak penyelenggara Perdagangan Melalui Sistem Elektronik (PMSE)/e-commerce, Pajak Pertambahan Nilai (PPN) untuk barang/jasa kena pajak dari luar daerah pabean, dipungut oleh pedagang/penyedia jasa Luar Negeri (LN), penyelenggara PMSE LN, dan penyelenggara PMSE Dalam Negeri (DN) yang ditunjuk Menkeu. Kemudian, Pajak Penghasilan $(\mathrm{PPh})$ atau pajak transaksi elektronik atas PMSE dipungut oleh subjek pajak Luar Negeri (LN). Penyedia barang/jasa LN, penyelenggara PMSE LN jika memenuhi ketentuan dapat diperlakukan sebagai BUT dan dikenai $\mathrm{PPh}$ dengan ketentuan yang diatur dalam PP dan Peraturan Menteri Keuangan (PMK). Sanksi bila terdapat pelanggaran, akan dilakukan pemutusan akses, dan teguran tertulis diatur dalam PMK. Pemerintah juga memberi perpanjangan waktu pelaksanaan hak dan kewajiban pajak selama masa penanganan Covid-19 
seperti pengajuan keberatan yang jatuh tempo dapat diperpanjang paling lama 6 bulan. Kemudian, pengembalian kelebihan pembayaran pajak dapat diperpanjang paling lama 1 bulan. Pelaksanaan hak wajib pajak (kelebihan pembayaran, surat keberatan, pengurangan/penghapusan sanksi) dapat diperpanjang paling lama 6 bulan. Waktu kahar pandemi mengacu pada Badan Nasional Penanggulangan Bencana (BNPB). Selain itu, Menkeu memiliki kewenangan untuk memberi fasilitas kepabeanan dengan pembebasan/keringanan Bea Masuk (BM) yang diatur PMK. (Kementerian Keuangan Republik Indonesia: 2020).

Penerimaan negara terdiri dari penerimaan dalam negeri Pemerintah dan hibah. Penerimaan dalam negeri Pemerintah terdiri atas Penerimaan Perpajakan yaitu Pajak dalam negeri berupa : (Dumairy:1997).

a. Pajak Penghasilan (PPh)

b. Pajak Pertambahan Nilai Barang dan Jasa (PPN) dan Pajak Penjualan atas Barang Mewah (PPnBM)

c. Pajak Bumi dan Bangunan (PBB)

d. Bea perolehan Hak atas tanah dan bangunan (BPHTB)

e. Pajak lainnya

f. Cukai.
Menurut Damayanti menguraikan fungsi-fungsi pajak sebagai berikut: (Damayanti dkk:2005).

a. Fungsi penerimaan (budgetair) yaitu fungsi sebagai sumber dana bagi pemerintah untuk membiayai pengeluaran-pengeluaran.

b. Fungsi mengatur (regulator) yaitu fungsi untuk mengatur atau mengeluarkan kebijakan-kebijakan pemerintah dari sudut social dan ekonomi. Berdasarkan kewenangan dalam pemungutannya, pajak dapat digolongkan menjadi Pajak Pusat dan Pajak Daerah.

Pertumbuhan komponen penerimaan Pajak hingga akhir bulan Maret 2020 masih bersumber dari pajak atas konsumsi rumah tangga, meskipun penerimaan pajak juga masih dipengaruhi tekanan akibat tren pelemahan industri manufaktur dan aktivitas perdagangan internasional, serta pelemahan aktivitas ekonomi akibat penyebaran Covid-19. Seiring adanya aturan terkait Work From Home (WFH) baik untuk sektor pemerintah maupun sektor swasta, maka mulai terjadi perlambatan kegiatan usaha di akhir bulan Maret 2020 yang berpotensi menurunkan penyerahan dalam negeri yang kemudian akan menekan penerimaan Pajak Pertambahan Nilai Dalam Negeri (PPN DN) di bulan 
April 2020. Kondisi tersebut kemungkinan berlanjut dan semakin terkontraksi di bulan Mei, mengingat di bulan April sebagian daerah sudah melaksanakan Pembatasan Sosial Berskala Besar (PSBB) di beberapa wilayah terdampak. Mengatasi kebijakan pemerintah terhadap dampak tersebut, pemerintah memberikan fasilitas perpajakan berupa relaksasi pembayaran PPh Pasal 29 Orang Pribadi (OP) dan pelaporan SPT PPh OP. Kebijakan makro-mikro penanggulangan wabah Covid-19 diharapkan akan dapat mempertahankan ekspektasi positif semua entitas ekonomi, baik di dalam negeri maupun luar negeri. Keputusan lockdown ini tidak diterapkan karena berbagai alasan termasuk kesiapan negara dalam menanggung resiko apabila lockdown terjadi. Sebagaimana yang terjadi di Indonesia, penerimaan pajak pada kuartal I-2020 tercatat mengalami kontraksi atau minus hingga 2,5\%. Adapun beberapa instrumen pajak yang minus setelah digunakan untuk penanganan Covid-19 adalah PPh Badan dan Pajak Dalam Rangka Impor (PDRI) terdiri beberapa jenis, yaitu Pajak Penghasilan (PPh) pasal 22 impor, PPh pasal 22 ekspor, Pajak Pertambahan Nilai (PPN) impor, dan Pajak Penjualan Barang Mewah (PPnBM). (Dina Eva Santi Silalahi:2020).

\section{c. Kebijakan Relaksasi Perpajakan dalam Peraturan Menteri Keuangan (PMK) Nomor 44/ PMK.03/2020, tentang Insentif Pajak untuk Wajib Pajak (WP) yang terkena dampak Corona Virus.}

Pemerintah telah menerbitkan Peraturan Menteri Keuangan (PMK) Nomor: 23/PMK.03/ 2020, tentang Insentif Pajak untuk Wajib Pajak yang terkena Virus Corona. Beberapa insentif yang diberikan termasuk, Pasal 21 Pajak Penghasilan $(\mathrm{PPh})$ ditanggung pemerintah, pembebasan impor Pasal $22 \mathrm{PPh}$, pengurangan Pasal $25 \mathrm{PPh}$, dan percepatan restitusi Pajak Pertambahan Nilai (PPN). Jumlah pelonggaran dimaksud adalah tertuang dalam Surat Keputusan Direktur Jenderal Pajak No.KEP-156/PJ/2020. Peraturan ini dibuat dan ditandatangani langsung oleh Direktur Jenderal Pajak Suryo Utomo pada tanggal 20 Maret 2020 dan mulai berlaku pada tanggal yang sama. Relaksasi Pasal 21 Pajak Penghasilan dengan memberikan pajak pemerintah $100 \%$ atas penghasilan pekerja yang memiliki penghasilan hingga Rp 200 juta per tahun di sektor manufaktur, baik yang berlokasi di KITE (Kawasan Industri Tujuan Ekspor) dan non-KITE. Relaksasi 
diberikan selama 6 bulan mulai dari gaji April hingga September. (Kementerian Keuangan Republik Indonesia: 2020). Pemberian insentif ini sebagai respon dari pemerintah atas menurunnya produktivitas para pelaku usaha karena roda perekonomian wajib pajak yang menurun drastis akibat wabah ini.

Pemerintah terus berusaha memberikan stimulus bagi perekonomian nasional. Dikutip dari situs kemenkeu.go.id, ada tambahan belanja APBN 2020 yang ditujukan untuk penanganan pandemik Covid-19, yaitu sebesar 255,1 triliun rupiah. Anggaran ini mencakup untuk bidang Kesehatan sebesar 75 triliun rupiah, Social Safety Net sebesar 110 triliun rupiah, dan dukungan dunia usaha (Perpajakan Ditanggung Pemerintah (DTP) yaitu; Pajak DTP dan Bea Masuk DTP) sebesar 70,1 triliun rupiah. Poin dukungan usahan termasuk di dalamnya komponen stimulus bagi Usaha Mikro Kecil dan Menengah (UMKM). Harapannya UMKM bisa bertahan di tengah pandemi virus korona. Terlebih dengan adanya kebijakan Pembatasan Sosial Berskala Besar (PSBB) yang membuat perputaran ekonomi melambat.

Dukungan dunia usaha, dalam hal ini UMKM, disahkan dalam Peraturan Menteri Keuangan Republik Indonesia
No. 44/PMK.03/2020 tentang Insentif Pajak untuk Wajib Pajak Terdampak Pandemi Corona Virus Disease 2019. Bab tersebut menguraikan tentang Insentif $\mathrm{PPh}$ Final berdasarkan Peraturan Pemerintah No. 23 tahun 2018 tentang Pajak Penghasilan Atas Penghasilan Dari Usaha Yang Diterima Atau Diperoleh Wajib Pajak Yang Memiliki Peredaran Bruto Tertentu. Pada peraturan sebelumnya yaitu PMK No. 23, insentif PPh Final ini tidak dimasukkan.

Kementerian Keuangan secara resmi menanggung $\mathrm{PPh}$ Final Usaha Mikro Kecil Menengah (UMKM) yang selama ini dipatok $0,5 \%$ dari peredaran bruto. Pelaku UMKM mendapat fasilitas pajak penghasilan final tarif 0,5\% (PP 23/2018) yang ditanggung pemerintah.

Direktur Penyuluhan, Pelayanan, dan Hubungan Masyarakat Direktorat Jenderal (Dirjen) Pajak Kemenkeu, Hestu Yoga Saksama mengungkapkan bahwa perkiraan besar insentif pajak penghasilan $(\mathrm{PPh})$ Final untuk UMKM itu sebesar Rp 2,4 triliun.

Ada perubahan dari PMK No.23 ke PMK No. 44. PMK No. 23 tahun 2020 memuat empat stimulus fiskal. $\begin{array}{llll}\text { Kemudian } & \text { di } & \text { PMK } & \text { No.44 }\end{array}$ tahun 2020 terdapat satu penambahan (perluasan) insentif $\mathrm{PPh}$ Final $0,5 \%$ 
Pajak Ditanggung Pemerintah. Lima stimulus berupa insentif tersebut yaitu:

1. Relaksasi Pasal 21 Pajak Penghasilan (PPh Pasal 21)

Relaksasi PPh 21 ditanggung pemerintah (bagi pekerja di seluruh sektor industri manufaktur yang punya income sampai 200 juta/tahun) dengan nilai ditanggung diperkirakan senilai 8,6 triliun rupiah. Relaksasi diberikan melalui skema Pajak Penghasilan Pasal 21 yang Ditanggung Pemerintah (DTP) sebesar $100 \%$ dari pendapatan pekerja hingga Rp 200 juta di sektor manufaktur (termasuk Kemudahan Impor Tujuan Ekspor/KITE dan Kemudahan Impor Tujuan Ekspor dari Usaha Kecil dan Menengah/IKM KITE). PPh DTP diberikan selama 6 bulan, mulai dari April hingga September 2020. Jumlah nilai yang ditanggung pemerintah adalah 8,6 triliun rupiah. Diharapkan bahwa pekerja di sektor manufaktur akan menerima pendapatan tambahan untuk mempertahankan daya beli. Insentif ini akan mempengaruhi penghasilan yang akan diterima oleh setiap pegawai selama 6 bulan ini. Jika sebelumnya pegawai dipotong $\mathrm{PPh}$ pasal 21 atas penghasilan, selama April sampai dengan September 2020 nanti pegawai akan menerima kembali potongan $\mathrm{PPh}$ 21. Potongan itu diberikan bersamaan dengan penghasilan bulanan yang diterima pegawai. Statusnya yang sebelumnya pajak ditanggung oleh si penerima penghasilan menjadi ditanggung oleh pemerintah atau disebut Pajak Ditanggung Pemerintah (PDP). Jadi, jika ada pemberi kerja yang menyalahi aturan terkait PMK ini akan dikenai sanksi sesuai dengan aturan yang berlaku.

2. Relaksasi Pasal 22 Pajak Impor (Pajak Penghasilan Pasal 22 Impor)

Relaksasi PPh 22 impor bagi 19 sektor industri manufaktur, baik di lokasi KITE (Kemudahan Impor Tujuan Ekspor) dan non KITE. Besar penundaan diperkirakan senilai 8,15 triliun upiah. Relaksasi diberikan melalui pembebasan skema pembebasan PPh Impor Pasal 22 untuk 19 sektor tertentu, Wajib Pajak KITE, dan Wajib Pajak IKM KITE. Pembebasan Pajak Penghasilan Pasal 22 Impor diberikan selama 6 bulan mulai dari bulan April hingga 
September 2020 dengan total perkiraan pembebasan 8,15 triliun rupiah. Kebijakan ini diadopsi sebagai upaya untuk menyediakan ruang arus kas bagi industri sebagai kompensasi untuk pengalihan biaya (biaya terkait dengan perubahan di negara asal impor). PPh Pasal 22 impor yang diberikan insentif berupa pembebasan pembayaran pajak. Pembebasan ini merupakan efek dari berkurangnya aktivitas pengiriman barang untuk masuk ke Indonesia guna mencegah penyebaran virus yang semakin masif perkembangannya di Indonesia, baik itu penghentian sementara dari negara asal atau pengurangan aktivitas belanja dari pelaku impor di Indonesia. Penurunan aktivitas impor ini sangat mempengaruhi neraca perdagangan Indonesia sehingga perlu diberikan sebuah stimulan melalui insentif agar wajib pajak yang menjadi pelaku usaha kembali semangat melakukan kegiatan di situasi tidak kondusif seperti ini. Bagi wajib pajak yang melakukan aktivitas impor akan diberikan pembebasan PPh Pasal 22 impor selama 6 bulan. Pemberian fasilitas ini diberikan melalui Surat
Keterangan Bebas (SKB) PPh Pasal 22 Impor kepada wajib pajak. Relaksasi 22 pajak pendapatan impor bagi mereka yang mengimpor barang mentah untuk 19 industri manufaktur yang terkena dampak sesuai dengan rekomendasi KADIN dan APINDO yang keduanya berlokasi di wilayah KITE dan non-KITE.

3. Relaksasi Pasal 25 Pajak Penghasilan (PPh Pasal 25)

Relaksasi PPh 25 bagi korporasi berupa potongan $30 \%$ bagi 19 sektor industri manufaktur, baik di lokasi KITE dan non KITE (berdasarkan rekomendasi KADIN dan APINDO). Besar Penundaan sekitar 4,2 triliun rupiah. Relaksasi diberikan melalui skema pengurangan pajak Pasal 25 dari $30 \%$ menjadi 19 sektor tertentu, Wajib Pajak KITE, dan Wajib Pajak KITE-IKM selama 6 bulan dari April hingga September 2020 dengan total perkiraan pengurangan 4,2 triliun rupiah. Seperti halnya dengan Pasal 22 relaksasi Pajak impor, melalui kebijakan ini diharapkan bahwa industri akan mendapatkan ruang arus kas sebagai kompensasi untuk biaya pengalihan (biaya terkait 
dengan perubahan di negara asal impor dan tujuan ekspor). Selain itu, dengan mengubah negara tujuan ekspor, diharapkan ekspor akan meningkat. PPh Pasal 25 yang akan menerima insentif dengan pengurangan besarnya angsuran sebesar $30 \%$ dari total angsuran yang seharusnya dibayar selama 6 bulan ke depan. PPh Pasal 25 masuk ke dalam aturan ini karena banyaknya pelaku usaha yang mulai berkurang aktivitasnya atau bahkan menghentikan usahanya untuk sementara selama wabah ini belum berhenti. Ketika kondisi seperti ini produktivitas wajib pajak menjadi turun akan tidak adil jika wajib pajak yang selama ini membayarkan angsuran jenis pajak ini tidak diberikan insentif. Selama peraturan ini, wajib pajak tidak perlu mengajukan pengurangan angsuran untuk mendapatkan insentif karena akan berlaku secara otomatis.

4. Relaksasi Restitusi Pajak Pertambahan Nilai (PPN)

Relaksasi restitusi PPN bagi perusahaan eksportir dipercepat tanpa audit awal dan tanpa batasan/plafon. Bagi perusahaan noneksportir dibatasi sampai 5 miliar rupiah. Besar restitusi 1,97

triliun rupiah. PPN yang diberikan insentif selama masa wabah Covid19 ini. Untuk PPN perlakuan pemberian insentif berbeda dengan ketiga jenis pajak sebelumnya. Insentif PPN yang diberikan adalah dengan kemudahan proses pemberian restitusi kepada Pengusaha Kena Pajak (PKP) yang telah ditentukan pada PMK 23 Tahun 2020 selama 6 bulan ke depan dimulai pada bulan April. Ada perbedaan batasan nominal restitusi yang diberikan kepada PKP Eksportir dan PKP Non Eksportir. Untuk PKP yang bertindak sebagai eksportir tidak ada batasan nominal PPN yang akan dilakukan restitusi sedangkan untuk PKP Non Eksportir diberikan percepatan restitusi dengan nilai paling banyak 5 miliar rupiah. Kepada PKP Eksportir mendapatkan fasilitas yang tak terbatas dalam pengajuan restitusi kali ini. Hal itu disesuaikan dengan penerapan tarif PPN yang selama ini diberikan oleh para eksportir. Bagi PKP yang masuk ke dalam klasifikasi yang mendapatkan insetif pajak untuk tidak perlu mengajukan permohonan penetapan PKP beresiko rendah ke KPP 
terdaftar. Relaksasi disediakan melalui pengembalian PPN yang dipercepat (pengembalian awal) untuk 19 sektor tertentu, WP KITE, dan WP KITE-IKM. Pengembalian pajak PPN dipercepat selama 6 bulan, mulai dari bulan April hingga September 2020 dengan total estimasi pengembalian sebesar 1,97 triliun rupiah. Tidak ada batasan pada nilai pengembalian PPN khusus untuk eksportir, sedangkan untuk non-eksportir jumlah pengembalian PPN ditetapkan maksimum 5 miliar rupiah. Dengan percepatan restitusi, wajib pajak bisa lebih optimal dalam menjaga likuiditas.

5. Insentif pajak bagi pelaku usaha UMKM yaitu PPh Final 0,5\%-nya ditanggung pemerintah.

\section{d. Efektivitas Kebijakan Perpajakan}

\section{Terhadap Stabilitas Ekonomi}

Indonesia Selama Pandemi Covid-

\section{9}

Krisis ekonomi global timbul akibat wabah virus Corona atau pandemi Covid-19, kegiatan logistik, pariwisata dan perdagangan merupakan sektor yang memperoleh dampak besar dari wabah virus Corona. Hal ini diakibatkan larangan sejumlah pemerintah untuk melakukan perjalanan ke luar negeri dan penutupan beberapa sektor pariwisata akibat dari kurangnya wisatawan mancanegara. Dampak sektor perdagangan, khususunya ekspor dan impor, bahan baku dan barang modal. Produksi turun, barang langka dan harga barang terus meningkat sehingga menimbulkan inflasi. Kenaikan harga barang yang disertai penghasilan yang menurun merupakan kondisi fatal daya beli masyarakat. Sebagian bahan baku untuk industri di Indonesia sendiri masih dipasok dari China yang mengalami kendala produksi akibat karantina di sejumlah daerah untuk membendung pandemi Covid- 19. (Syahriyah Semaun: 2020).

Saat ini ekonomi global mengalami krisis akibat pandemi Covid19, indeks bursa saham rontok. Nilai tukar rupiah terhadap dollar USA melemah hal ini diakibatkan banyaknya investor asing meninggalkan pasar keuangan Indonesia, pasar saham anjlok, mempengaruhi perekonomian dalam negeri. Penguatan dollar USA ini terjadi karena kepanikan di pasar global akibat Covid-19 serta bergejolaknya pasar minyak. Kemungkinan rupiah akan melemah terus terhadap nilai tukar dollar AS. Dibutuhkan penanganan yang serius dan kebijakan yang tegas dan tepat 
sasaran untuk menyelesaikan krisis ekonomi tersebut.

Untuk mendorong pertumbuhan ekonomi agar tetap berjalan di tengah krisis ekonomi akibat wabah covid-19, Pemerintah Indonesia telah mengeluarkan stimulus yang terangkum ke dalam 3 stimulus yaitu stimulus fiskal, non fiskal dan sektor ekonomi.

Ketiga stimulus tersebut berkaitan dengan berkaitan dengan kebutuhan masyarakat dalam bidang usaha, bisnis, pajak dan sebagainya. (Syahriyah Semaun: 2020)

Stimulus fiskal untuk mendorong pertumbuhan ekonomi masyarakat, seperti:

a) Pembebasan sementara pajak penghasilan atau PPh pasal 21 selama 6 bulan untuk industri pengolahan. Hal ini dapat mempertahankan daya beli pekerja yang bekerja di sektor industri. Peraturan ini mulai berlaku bulan April hingga September 2020.

b) Penundaan pembayaran penghasilan impor atau PPh pasal 22 selama 6 bulan. Peraturan Ini mulai berlaku bulan April hingga September 2020.

c) Pengurangan pajak $\mathrm{PPh}$ pasal 25 sebesar $60 \quad \%$ selama 6 bulan. Peraturan ini mulai berlaku bulan April hingga September 2020. Hal ini diharapkan dapat memberikan ruang cash flow bagi industri dengan penundaan pajak, berlaku mulai bulan April hingga September 2020

d) Pembebasan pajak restoran dan hotel selama 6 bulan. Kebijakan tersebut diberlakukan untuk 10 destinasi wisata dan 33 kota dan kabupaten. Peraturan ini mulai berlaku bulan April hingga September 2020.

e) Relaksasi restitusi untuk pajak pertambahan nilai atau PPN dipercepat selama 6 bulan. Hal ini diharapkan dapat membantu likuiditas perusahaan dampak dari pandemi Covid-19.

Ekonomi adalah aliran sirkuler terpadu yang terdiri dari masyarakat konsumen dan produsen. Sederhananya, pengeluaran satu entitas adalah makanan untuk entitas lain. Produksi dari satu entitas tidak hanya barang dan jasa yang siap untuk dikonsumsi, tetapi juga pendapatan untuk rumah tangga yang bekerja di pabrik dan rumah tangga produksi. Dalam hal pelaku sektor produksi, perekonomian Indonesia didominasi oleh Usaha Mikro, Kecil dan Menengah (UMKM). Data dari Kementerian Koperasi dan UKM menyebutkan, pada tahun 2019, entitas 
produksi Indonesia didominasi oleh UMKM, yaitu 99,99 persen dari total jumlah unit bisnis yang ada. Sementara itu, dalam hal nilai tambah, UMKM berkontribusi sekitar> $40 \%$ dari Produk Domestik Bruto (PDB). (Sumantoro:2007).

Dalam hal ukuran jumlah pekerja dan omset, yang terkecil adalah usaha mikro dengan kontribusi nilai tambah sekitar 34 persen dari PDB. Sedangkan entitas berjumlah sekitar 98 persen dari 63 juta total unit bisnis yang ada, termasuk perusahaan besar. Tidak seperti karyawan kerah putih di kantor, untuk bisnis mikro dan pekerja, hidup adalah dari hari ke hari dengan mengandalkan omset dan pendapatan harian. Omzet bisnis mikro per tahun rata-rata sekitar Rp. 76 juta, artinya Rp. 6 juta sebulan atau Rp. 200.000 per hari. Untuk grup ini, akses dan peluang untuk menjual produk mungkin lebih penting daripada bantuan tunai dan kredit.

Pelonggaran pajak diharapkan dapat meningkatkan arus kas Indonesia karena dapat membantu meningkatkan pendapatan kotor suatu negara. Ini adalah dampak positif jika pelonggaran pajak dilakukan pada pasal 21, 22, dan 25. Oleh karena itu Menteri Keuangan dan stafnya yang mengurus pelonggaran pajak bertujuan untuk membuat arus kas keuangan Indonesia stabil. Diatur dalam PMK 28/2020 tidak hanya mengatur pelonggaran pajak tetapi pemerintah juga mengatur stimulus ekonomi dengan kemudian menggunakan instrumen pajak untuk mendukung ketersediaan obatobatan, peralatan medis, dan alat pendukung lainnya yang diperlukan dalam menangani wabah virus Corona. (Kompas: 2020).

Relaksasi Pajak adalah cara paling efektif untuk mengatasi perekonomian Indonesia. Menteri Keuangan Sri Mulyani menyatakan bahwa pengurangan tarif pajak (relaksasi) memang menghasilkan penurunan pendapatan negara. Namun, tarif pajak penghasilan badan saat ini sebesar 25 persen jika diturunkan dapat berdampak pada peningkatan pertumbuhan ekonomi. Kebijakan ekonomi pemerintah dalam bentuk insentif pajak dan stimulus sebagai upaya untuk mengurangi dampak pandemi Covid-19, merupakan angin segar bagi dunia bisnis. Melalui kebijakan ini, diharapkan dunia bisnis tidak akan gagal setelah pandemi dan ekonomi Indonesia dapat tetap stabil. (M. H. Munandar: 2020).

Pendapat dari penulis untuk menyelematkan ekonomi Negara dari dampak pandemi Covid-19, maka pelonggaran pajak yang dicurahkan oleh 
pemerintah perlu diperluas ke sektor lain. Untuk saat ini, pemerintah telah melonggarkan pengenaan Pajak Penghasilan Pasal 21, Pajak Penghasilan Pasal 22, Pajak Penghasilan Pasal 25, dan pengembalian pajak PPN khusus ke sektor manufaktur. Jadi menurut penulis, pelonggaran pajak penghasilan dalam pasal 21, 22, dan pasal 25 serta pengembalian pajak adalah hal yang paling efektif dan tepat dalam mengatasi dampak ekonomi Indonesia dalam menghadapi wabah Covid-19.

\section{KESIMPULAN}

Dalam menghadapi pandemik Covid-19 ini, pemerintah menerapkan berbagai kebijakan perpajakan untuk menjaga pertumbuhan ekonomi maupun kestabilan perekonomian. Kebijakan di bidang perpajakan melalui penerbitan Peraturan Pemerintah Pengganti UndangUndang Nomor 1 Tahun 2020, antara lain meliputi: 1) Penyesuaian tarif Pajak Penghasilan Wajib Pajak badan dalam negeri dan bentuk usaha tetap; 2). Perlakuan perpajakan dalam kegiatan Perdagangan Melalui Sistem Elektronik (PMSE); 3). Perpanjangan waktu pelaksanaan hak dan pemenuhan kewajiban perpajakan; dan 4). Pemberian kewenangan kepada Menteri Keuangan untuk memberikan fasilitas kepabeanan berupa pembebasan atau keringanan bea masuk dalam rangka penanganan kondisi darurat serta pemulihan dan penguatan ekonomi nasional. Penulis menyimpulkan bahwa kebijakan pajak dilakukan oleh Pemerintah Indonesia sudah efektif. Namun, keefektifan ini membutuhkan langkah-langkah pendukung lainnya untuk mencapai efektifitas sempurna dan dapat meningkatkan pertahanan ekonomi Indonesia, langkah pendukungnya antara lain kebijakan relaksasi pajak. Sudah tepat jika Indonesia menerapkan kebijakan relaksasi pajak, salah satu kebijakan relaksasi pajak adalah membuat karyawan tidak perlu membayar $\mathrm{PPh}$ untuk 6 April-September. Di beberapa negara, pelonggaran pajak dapat berhasil meningkatkan stabilitas ekonomi suatu negara. Melalui pandemi Covid-19, pemerintah Indonesia dapat belajar bertindak tegas dalam mengambil keputusan. Karena dengan kejadian tak terduga ini pemerintah harus bisa bertindak tegas untuk mengatasi semua masalah yang ada, dengan mengeluarkan kebijakan untuk menangani masalah yang ada di masyarakat khususnya bidang perekonomian, moneter dan fiskal. Kebijakan penerbitan Peraturan Pemerintah Pengganti Undang-Undang Nomor 1 Tahun 2020 dan relaksasi pajak 
dianggap efektif untuk mengatasi masalah keuangan Negara dan ekonomi yang tidak stabil akibat pandemi Covid-19.

\section{DAFTAR PUSTAKA}

\section{a. Sumber Buku}

Damayanti dkk, Perpajakan Indonesia. Salatiga: Andi, 2005.

Dumairy, Perekonomian Indonesia. Jakarta: Erlangga, 1997.

I. Wayan Sudirman. (2014). Kebijakan Fiskal dan Moneter: Teori dan Empirikal. Jakarta: Kencana.

Saraclaers. (1993). Social Research. Australia: Macmillan Education.

Sudiyono R. (1985). Ekonomi Makro : Analisis IS-LM dan PermintaanPenawaran Agregat. Yogyakarta.Liberty.

Sumantoro. (2007). Hukum Ekonomi. Depok: UI Press.

\section{b. Sumber Jurnal}

Dina Eva Santi Silalahi Strategi Kebijakan Fiskal Pemerintah Indonesia dalam Menghadapi Dampak Pandemi Covid-19, J. Ekon. Ekon. Syariah, vol. 3, no. 2, pp. 156-167, 2020.

Henny Juliani. (2020). Analisis Yuridis

Kebijakan Keuangan Negara dalam Penanganan Pandemi Covid-19 Melalui Peraturan Pemerintah Pengganti UndangUndang Nomor 1 Tahun 2020, Adm. Law Gov. Journal., vol. 3, no. 2, pp. 329-347.
Indra Maipita, dkk. (2010). Dampak Kebijakan Fiskal Terhadap Kinerja Ekonomidan Angka Kemiskinan Di Indonesia. Bul. Ekon. Monet. Dan Perbank., vol. 12 , no. 4, p. 421

M. H. Munandar. (2020). Analysis The Effectiveness of Tax Relaxation Due To Covid-19 Pandemic On Indonesian Economic Defense. Lex Sci. Law Rev., vol. 2, no. 1, pp. 133-142.

\section{c. Sumber Internet}

Ikatan Akuntan Indonesia. (2020). Relaksasi Aturan Djp Kementerian Keuangan Menghadapi Pandemi Covid-19. Diakses Juli 2020 dari http://iaiglobal.or.id/v03/beritakegiatan/detailberita-1240relaksasi-aturan-djp-kementeriankeuangan-menghadapi-pandemicovid19.

Kementerian Keuangan Republik Indonesia. (2020). Ini Daftar Kebijakan Keuangan Negara dalam Perppu No.1 Tahun 2020. Diakses Juli 2020 dari https://www.kemenkeu.go.id/publi kasi/berita/ini-daftar-kebijakankeuangan-negara-dalam-perppuno1-tahun-2020/.

Kementerian Keuangan Republik Indonesia. (2020). Daftar Relaksasi Pajak Untuk Mitigasi Dampak-Negatif Virus Pada Ekonomi. Diakses Juli 2020 dari https://www.kemenkeu.go.id/publi kasi/berita/ini- daftar-relaksasipajak-untuk-mitigasi-dampaknegatif-virus-corona-padaekonomi/. 
Media Kompas.(2020). Insentif Pajak Di Tengah Virus Corona Jadi Angin Segar Dunia Usaha. Diakses Juli 2020 dari https://money.kompas.com/read/20 20/04/13/122602526/insentifpajak-di-tengah-virus-corona-jadiangin- segar-dunia-usaha .

Syahriyah Semaun. (2020). Dampak Pandemi Covid-19; Stimulus Di Tengah Krisis Ekonomi Global. Diakses Juli 2020 dari http://www.iainpare.ac.id/dampakpandemi-covid-19-stimulus-ditengah-krisis-ekonomi-global/2/.

\section{d. Sumber Peraturan Perundang- Undangan}

Undang-Undang Nomor 16 Tahun 2009 tentang Perubahan ke empat Undang Nomor 6 Tahun 1983 tentang Ketentuan Umum dan Tata Cara Perpajakan.
Undang-Undang No.36 Tahun 2008 tentang Pajak Penghasilan

Peraturan Pemerintah Pengganti UndangUndang (Perppu) Nomor 1 Tahun 2020 tentang Kebijakan Keuangan Negara Dan Stabilitas Sistem Keuangan Untuk Penanganan Pandemi Corona Virus Disease 2019 (Covid-19) Dan/Atau Dalam Rangka Menghadapi Ancaman Yang Membahayakan Perekonomian Nasional Dan /Atau Stabilitas Sistem Keuangan. Indonesia, 2020.

Peraturan Menteri Keuangan Republik Indonesia No. 44/PMK.03/2020 tentang Insentif Pajak

Surat Keputusan Direktur Jenderal Pajak KEP-156/PJ/2020 tentang Kebijakan Perpajakan Sehubungan Dengan Penyebaran Wabah Virus Corona 2019 